\title{
Feasibility of rating fire blight susceptibility of pear cultivars (Pyrus communis) on in vitro mi- crocuttings
}

Marie-Noëlle BRISSET, Jean-Picrre PAULIN \& Michel DURON $\left({ }^{*}\right)$

I.N.R.A., Station de Pathologie végétale, F 49000 Angers

(*) I.N.R.A., Station d'Amélioration des Espèces fruitières et ornementales, F 49000 Angers

Typical symptoms of fire blight (ooze production and necrosis) can easily be obtained from the inoculation of $i$ vitro microcuttings of a host plant. The purpose of the study was to determine whether the susceptibility of pear cultivars to fire blight can be evaluated in vitro. In a work based on several Pyrus cultivars (susceptible and resistant) propagated in vitro, the effects of different external factors (method of inoculation, concentration of inoculum, growing conditions) on quantitative and qualitative expression of symptoms were analyzed. The variability of the results, already noticed in orchards, was not lessened on this plant material. Inoculations on in vitro microcuttings usually overestimated susceptibility. However, a decrease of the receptivity of susceptible cultivars was sometimes observed. Therefore tests on in vitro microcuttings do not seem to be suitable for accurate discrimination between cultivars based on their different levels of susceptibility. Nevertheless these tests may bc useful for selecting out individuals with high levels of resistance from a population (i.e. after mutagenic treatment or induction of somaclonal variations).

Additional key words : Temperature, light, conditions of inoculation.

RÉSUMÉ

\begin{abstract}
Est-il possible d'établir une échelle de sensibilité variétale au feu bactérien sur des microboutures de poirier (Pyrus communis).

Si les symptômes typiques du feu bactérien (production d'exsudat et nécrose) sont facilement obtenus sur microboutures in vitro de plantes-hôtes inoculées, est-il possible d'estimer la sensibilité d'un cultivar donné? Travaillant sur différents cultivars de Pyrus (sensible et résistant) multipliés in vitro, l'effet de facteurs externes (méthode d'inoculation, concentration d'inoculum, conditions de culture) sur l'expression quantitative et qualitative de la maladie est analysé. La variabilité des résultats, déjà connuc en verger, n'est pas réduite par l'utilisation de ce matériel végétal. Des inoculations sur microboutures donnent souvent une surestimation de la sensibilité mais on observe parfois une diminution de la réceptivité de cultivars sensibles. Ainsi, un test sur microboutures ne paraît pas approprié pour différencicr précisément des sensibilités variétales. Cependant, il peut être utilisé pour sélectionner des individus très résistants à l'intérieur d'une population (par exemple après un traitement mutagène ou l'induction de variations somaclonales).
\end{abstract}

Mots clés additionnels : Température, lumière, conditions d'inoculation.

ABBREVIATION : CFu, colony.

\section{INTRODUCTION}

Fire blight, a disease of many Rosaceous plants (especially pear and apple), is caused by the bacterium Erwinia amylovora. When this disease is newly introduced into an area, at least two questions have to be answered rapidly. First, what is the susceptibility of locally grown cultivars? A minimum of five years is needed to get this answer (LE Lezec et al., 1985).
Second, will new resistant cultivars be available? This second question will take as many as fifteen to twenty years to answer (LeSPINASSE, PAULIN, 1984). In these two cases a test allowing for rapid screening would be of considerable interest.

According to Viseur \& TAPIA y Figueroa (1987), pear cultivar susceptibility can be rated fairly precisely on in vitro plant material. However, in our previous 
work (DuRon et al., 1987) this was not so obvious. Thus, using in vitro propagated microcuttings of pear, the influence of several external factors on the expression of the disease has been studied in order to decide if a scale of varietal susceptibility could be properly established, based on such plant material.

\section{MATERIAL AND METHODS}

\section{A. Plant material}

The three pear cultivars : Passe Crassane, Doyenné du Comice (susceptible) and Old Home (resistant) were chosen because of their known behaviour in the field. The cultivars were propagated on a mineral solution of Lepoivre (QUOIRIN et al., 1977) supplemented with the following: sucrose $30 \mathrm{~g} \mathrm{l}^{-1}$; agar $6.5 \mathrm{~g} \mathrm{l}^{-1}$; vitamins $\left(\mathrm{mg} \mathrm{l}^{-1}\right)$ : inositol $(100)$, thiamine $(0.8)$, nicotinic acid (1) pyridoxine $\mathrm{HCl}(0.1)$, glycine (4); hormone $\left(\mathrm{mg} \mathrm{l}^{-1}\right)$ : 6-benzyl aminopurine $(0.5)$, indol-3-butyric acid $(0.1)$.

The inoculations were performed on the youngest, unfolded leaf of unrooted microcuttings. Tips of actively growing stems (about $1.5 \mathrm{~cm}$ long) were subcultured on LEPOIVRE medium one week before inoculation.

\section{B. Inoculum}

All the inoculations were made with an aggressive strain of E. amylovora: strain CFBP 1430 (Collection française de Bactéries Phytopathogènes - I.N.R.A. Angers), cultivated on KING's medium B (KING et al., 1954). Bacterial suspensions were prepared with cultures in the exponential stage of growth.

\section{Method of inoculation}

One leaf per microcutting was punctured with teethnosed dissecting forceps previously dipped into a bacterial suspension. This method was more efficient as the number of punctures increased (up to 3) (DuRON et al., 1987).

\section{Growing conditions}

Before inoculation, the conditions of the growth room were $16 \mathrm{~h}$ of light $\left(3000 \mathrm{lux}, 26.9 \mu \mathrm{mol} \mathrm{m}{ }^{2} \mathrm{~s}^{-1}, 400-\right.$ $700 \mathrm{~nm}$ ) at $24^{\circ} \mathrm{C}, 8 \mathrm{~h}$ of darkness at $20^{\circ} \mathrm{C}$.

After inoculation, the incubation temperatures applied $\left(17,24,26,30^{\circ} \mathrm{C}\right)$ were constant day and night. The experiments were done under dark conditions except for a particular experiment that studied the effect of light, in which case the photoperiod was $18 \mathrm{~h}$ light, $6 \mathrm{~h}$ darkness. Light was supplied by fluorescent tubes and incandescent lamps. Different qualities of light were obtained with filters according to LE DEUNFF (1971) : a sheet of red Sceneroid $n^{\circ} 227$ to obtain red light : three sheets of Sceneroid (one green $n^{\circ} 216$, one blue $n^{\circ} 212$, one red $n^{\circ} 227$ ) to obtain far red light.

Microcuttings were placed under the filters in order to receive an illuminance around 15000 lux. That means in photon flux density, for each quality of light: white illumination, $275.2 \mu \mathrm{mol} \mathrm{m}{ }^{2} \mathrm{~s}^{-1}(400-700 \mathrm{~nm})$; red, $166.3 \mu \mathrm{mol} \mathrm{m}^{2} \mathrm{~s}^{-1} \quad(580-700 \mathrm{~nm}) ;$ far red, 79.3 $\mu \mathrm{mol} \mathrm{m}{ }^{-2} \mathrm{~s}^{-1}(700-850 \mathrm{~nm})$.

\section{E. Symptom assessment}

Microcuttings were considered diseased if necrosis extended at least to the petiole of the inoculated leaf, which is assumed to be the beginning of a progressive infection. Readings were made every 2 or 3 days up to a maximum of 14 days after inoculation.

The number of plants per treatment was : 3 replicates of 6 plants per treatment for the experiment studying the effect of the concentration of inoculum ; 3 replicates of 4 plants per treatment and per cultivar for the experiment studying the effect of temperature ; 3 replicates of 16 plants per treatment for the experiment studying the effect of the quality of light.

\section{RESULTS}

\section{A. Concentration of inoculum}

Susceptibility varied with the concentration of inoculum up to a threshold level after which a plateau was reached (fig. 1). The turning point appeared to be around $5 \times 10^{7} \mathrm{cfu} / \mathrm{ml}$. Thirteen days after inoculation there were 89 to $100 \%$ diseased microcuttings with $5 \times 10^{7} \mathrm{cfu} / \mathrm{ml}$ or more and only about $39 \%$ of the microcuttings showed symptoms with $1 \times 10^{7}$ and $5 \times 10^{6} \mathrm{cfu} / \mathrm{ml}$.

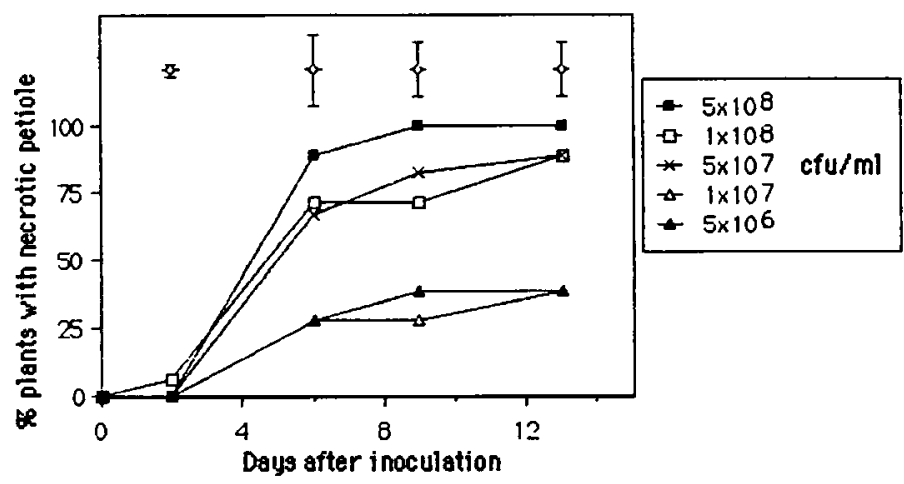

Figure 1

Effects of inoculum concentration on in vitro susceptibility to fire blight of the pear cultivar Dovenne du Comice.

Effet de la concentration d'inoculum sur la sensibilité in vitro au feu bactérien de la varićté Doyenné du Comice.

Vertical bars are standard errors of means.

Les segments verticaux représentent les intervalles de confiance des moyennes.

\section{B. Growing conditions}

\section{Temperature}

The length of time between inoculation and the first observation of symptoms on susceptible cultivars 
decreased as the temperature increased. But whatever the temperature, the final susceptibility rating was the same. Figure 2 shows the results of Passe Crassane. Those of Doyenné du Comice were similar.

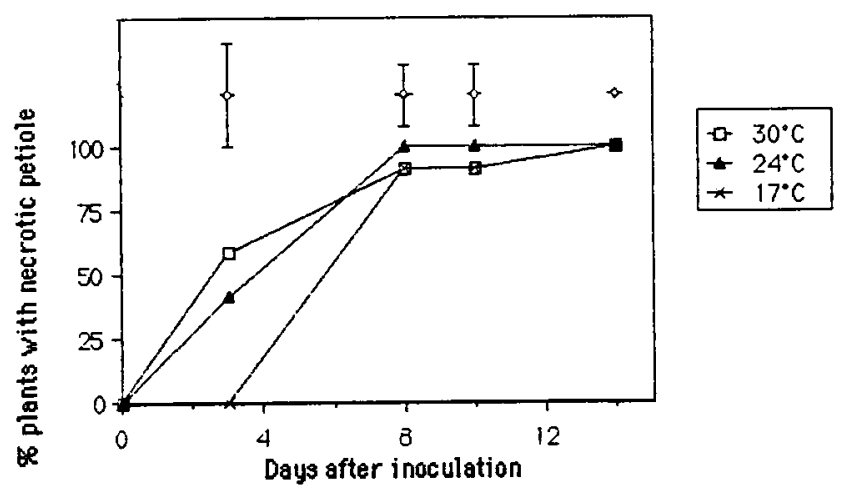

Figure 2

Effect of temperature on in vitro susceptibility to fire blight of the pear cultivar Passe Crassane.

Effet de la température sur la sensibilité in vitro au feu bactérien de la variété Passe Crassane.

Vertical hars are standard errors of means.

Les segments verticaux représentent les intervalles de confiance des moyennes.

For the cultivar Old Home, an increase of temperature tended to decrease the resistance of microcuttings although our results were not statistically significant (fig. 3).

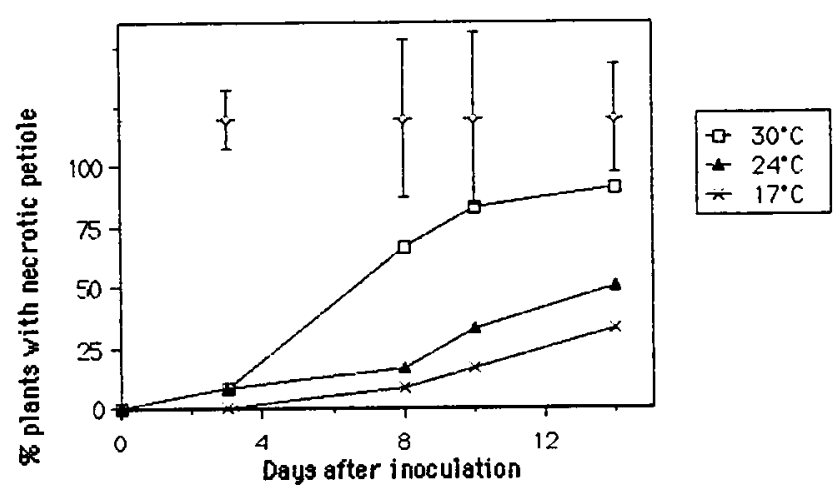

Figure 3

Effect of temperature on in vitro susceptibility to fire blight of the pear cultivar Old Home.

Effet de la température sur la sensibilité in vitro an feu bactérien du cultivar Old Home.

Vertical bars are standard errors of means.

Les segments verticaux représentent les intervalles de confiances des movennes.

\section{Conditions of illumination}

Susceptible microcuttings (Passe Crassane) placed in the dark or under far red illumination were significantly more susceptible than those placed under normal conditions of illumination. Microcuttings illuminated with red light showed an intermediate susceptibility (fig. 4).

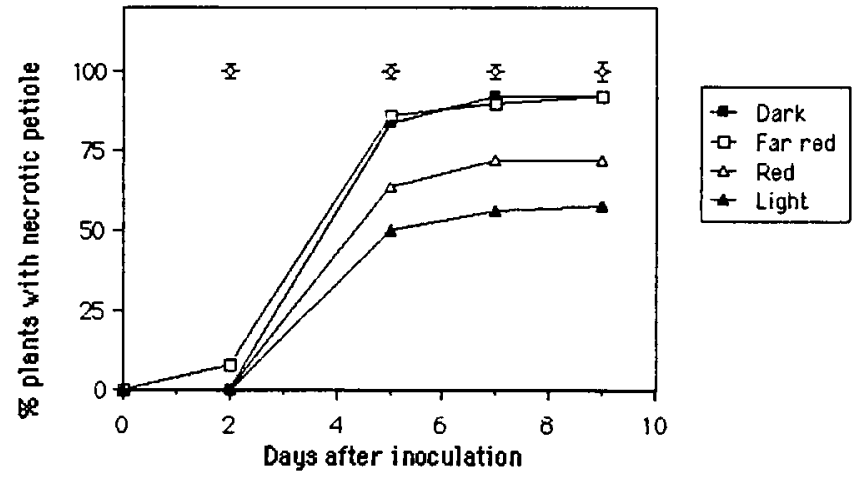

Figure 4

Effect of conditions of illumination on in vitro susceptibility to fire blight of the pear cultivar Passe Crassane.

Effet des conditions d'éclairement sur la sensibilité in vitro au feu bactérien de la variété Passe Crassane.

Vertical bars are standard errors of means.

Les segments verticaux représentem les intervalles de confiance des molennes.

\section{DISCUSSION}

Artificial inoculations cannot be performed on in vitro microcuttings as they are in orchards. The inoculum in an orchard is forced into the shoot below the apex with a syringe. In vitro, the microcuttings are first wounded and then the inoculum is deposited on the wound. There can be a risk that the plantlet is too heavily wounded to remain receptive to inoculation. The method of inoculation with teeth-nosed dissecting forceps has been found to be satisfactory, provided that the concentration of inoculum is high enough $\left(5 \times 10^{7}\right.$ to $\left.5 \times 10^{8} \mathrm{cfu} / \mathrm{ml}\right)$.

Environmental factors have great influence on the development of fire blight. This influence, well-known in the orchard, also exists on in vitro microcuttings, and is particularly easy to study on such material.

As far as temperatures are concerned, our results with susceptible varieties can be discussed in the light of those of BILLING (1974). She studied in vitro the effect of temperature on the growth of E. amylovora and found that $18^{\circ} \mathrm{C}$ was a turning point. Below $18^{\circ} \mathrm{C}$, growth increased rapidly with increasing temperature. Above $18^{\circ} \mathrm{C}$, the increase of growth with temperature was less. Actually in our inoculations with susceptible cultivars, an increase of temperature (from $17^{\circ} \mathrm{C}$ to $30^{\circ} \mathrm{C}$ ) did have the expected effect on the growth rates of E. amylovora, leading to earlier symptoms. Nevertheless, the overall rating of the cultivars remained the same, because the final amount of disease was constant whatever the temperature. In contrast, for the resistant cultivar, an increase of temperature induced a higher frequency of diseased microcuttings. One explanation could be that high temperature $\left(30^{\circ} \mathrm{C}\right)$ acts on the plant physiology, and this lessens resistance of such cultivars.

In regard to the illumination conditions, we have previously shown that dark conditions increased the development of necrosis when compared with photoperiodic conditions (Duron et al., 1987). In the present study, darkness and far red light increased susceptibility of our microcuttings, as compared with red or white 
illumination. It is to be emphasized that the far red and dark conditions promote the photoconversion of $\mathrm{Pfr}$ (phytochrome in the far red absorbing form) to $\mathrm{Pr}$ (phytochrome in the red absorbing form). The higher susceptibility of the microcuttings could then possibly be associated with a low Pfr content: this hypothesis remains to be tested.

The studies on the effects of the environmental factors described here would have been performed with great difficulty in the orchard or even in the greenhouse. This points out the interest in the use of in vitro propagated plant material. But although this method permits the control of most if not all external factors, the results show a surprising variability and are not systematically better than those obtained in the orchard. For example, inoculations of Doyenne du Comice with the two concentrations of inoculum: $1 \times 10^{7}$ and $5 \times 10^{7}$ (fig. 1) gave two significantly different frequencies of diseased microcuttings after 13 days : 39 and 89 respectively. Such a difference in the rating of the same variety is not usually observed in the orchard where the experimental conditions (including concentration of inoculum) are not so strictly controlled.
On account of this variability, we think that it is difficult to determine a real scale of varietal susceptibility based on in vitro propagated microcuttings. Nevertheless, it is possible to select highly resistant individuals within a population. The response of such resistant microcuttings to artificial inoculation is of low variability whatever the conditions (except under extreme temperature conditions : $30^{\circ} \mathrm{C}$ ). An in vitro test therefore can be used as a preliminary and rapid screening after any treatment of plants aimed at the induction of variability among a homogeneous population, such as mutagenesis, somaclonal variation and transformation.

Reçu le 12 fóvier 1988 Accepte le 9 juin 1988

\section{ACKNOWLEDGMENTS}

We are thankful to Prof. LENORMAND who provided us with special filters and for fruitful discussions.

We thank Prof. H. S. Aldwincki.r. for useful comments and suggestions.

A part of this work has been supported by EEC grant $n^{\circ} 4012$.

M. N. BRISSET is recipient of a fellowship (CIFRE) from Ministere de la Recherche and Riker/3M Co.

\section{REFERENCES}

Billing E., 1974. The effect of temperature on the growth of the fire blight pathogen, Erwinia amylovora. J. appl. Bact., 37, 643-648.

Duron M., Paulin J.-P., Brisset M.-N., 1987. Use of in vitro propagated plant material for rating fire blight susceptibility. Acta Hortic., 217, 317-324.

King E. O., Ward M. K., Raney D. E., 1954. Two simple media fer the demonstration of pyocyanin and fluorescin. J. Laborat. Clinic. Med., 44, 301-307.

Le Deunff Y., 1971. Mise en évidence du phytochrome chez. les semences de Rumex crispus L. Physiol, veg., 9 (2), 201-208.

Le Lezec M., Thibault B., Balavoine P., Paulin J.-P., 1985. Sensibilité varictale du pommicr et du poiricr au feu bactérien. Phytoma, 2 , $37-44$.

Quoirin H., Lepoivre Ph., Boxus Ph., 1977. Un premier bilan de 10) années de recherches sur les cultures de méristèmes et la multiplication in vifro de fruitiers ligneux. Station des cultures fruitières et maraichères. Cent. Rech. Agron. de l'Etat. B 58000 Gembloux, Belgique. C. R. Rech., annces 1976-1977, 93-117.

Lespinasse Y., Paulin J.-P., 1984. Apple breeding programme for fire blight resistance. Acta Hortic., 151, 301-305.

Viseur J., Tapia y Figueroa M., 1987. In vitro co-culture as a tool for the evaluation of fireblight resistance in pears and apples. Acta Hortic., 217, 273-282. 